http://jurnal.unmer.ac.id/index.php/ap

\title{
Pengaruh Inflasi, Nilai Tukar, Suku Bunga, Dan Volume Transaksi Terhadap Harga Saham Perusahaan Pada Kondisi Pandemi Covid-19
}

\author{
Serena Sila Sebo ${ }^{1}$, H. Moch. Nafi ${ }^{2}$ \\ 1 Universitas Merdeka Malang, Jl. Terusan Raya Dieng 62-64, Malang, 65146, Indonesia \\ 2Universitas Merdeka Malang, Jl. Sudimoro 373, Malang, 65171, Indonesia
}

Keywords:

Covid-19 Pandemic; Exchange Rates; Inflation; Interest Rates; Share Prices; and Transaction Volume.

Kata Kunci:

Harga Saham; Inflasi, Nilai Tukar; Pandemi Covid-19; Suku Bunga; dan Volume Transaksi

\begin{abstract}
This study aims to determine the effect of inflation, exchange rates, interest rates, and transaction volume on stock prices of companies in the food and beverage sector. The method used in this research is quantitative method with multiple linear analysis. In this study using 5 samples of food and beverage sector companies listed on the IDX in the period MarchSeptember 2020 based on certain criteria. The results of the study found that partially inflation, exchange rates, and interest rates have no significant effect on stock prices, while transaction volume has a positive and significant effect on stock prices. The research results simultaneously state that inflation, exchange rates, interest rates and transaction volume have a significant effect on stock prices.
\end{abstract}

\begin{abstract}
ABSTRAK
Penelitian ini bertujuan untuk mengetahui pengaruh inflasi, nilai tukar, suku bunga, dan volume transaksi terhadap harga saham perusahaan sektor makanan dan minuman. Metode yang digunakan dalam penelitian ini adalah metode kuantitatif dengan analisis linear berganda. Dalam penelitian ini menggunakan 5 sampel perusahaan sektor makanan dan minuman yang terdaftar di BEI pada periode maret-september 2020 berdasarkan kriteria-kriteria tertentu. Hasil penelitian menemukan bahwa secara parsial inflasi, nilai tukar, dan suku bunga tidak berpengaruh signifikan terhadap harga saham, sedangkan volume transaksi berpengaruh positif dan signifikan terhadap harga saham. Hasil penelitian secara simultan menyatakan bahwa inflasi, nilai tukar, suku bunga dan volume transaksi berpengaruh signifikan terhadap harga saham.
\end{abstract}

\section{PENDAHULUAN}

Diawal tahun 2020, dunia dikejutkan dengan kemuculan virus baru yang menyerang sistem pernapasan manusia. Virus ini secara internasional oleh Organisasi Kesehatan Dunia atau WHO diberi nama COVID-19 atau Corona Virus Disease 19 yang ditetapkan oleh negara Indonesia sebagai pandemi pada tanggal 2 Maret 2020. Upaya-upaya yang dilakukan negara-negara di dunia termasuk Indonesia dalam 
menangani pandemi ini adalah dengan melakukan physical distancing, penggunaan masker, meliburkan sekolah, melakukan work from home (bekerja dari rumah), dan banyak hal lainnya termasuk melakukan lockdown. Merebaknya pandemi ini tidak hanya berdampak pada kesehatan tetapi juga secara tidak langsung berdampak pada perekonomian. Banyak sektor-sektor tertentu yang terdampak pandemi ini. Ada beberapa perusahaan yang melakukan Pemutusan Hubungan Kerja (PHK), misalnya yang dilakukan oleh Ramayana di daerah Depok. Terdapat 87 karyawan Ramayana di City Plaza Depok, terkena pemutusan hubungan kerja (PHK). Menurut Camelia (2020), "Kepada Liputan6.com, Store Manager City Plaza Depok, M Nukmal Amdar mengatakan, perusahaan memutuskan tidak lagi beroperasi sejak 6 April 2020. Keputusan ini diambil lantaran omzet penjualan menurun hingga 80 persen. Akibatnya, perusahaan pun tak mampu lagi menanggung semua biaya operasional". Pandemi membuat aktivitas dunia terhambat. Wabah pandemi corona atau COVID-19 telah menggoyang pasar saham dan pasar keuangan di dalam negri, hingga mencetak rekor baru. Dan mengakibatkan Indeks Harga Saham Gabungan atau ( IHSG ) anjlok dan terpukul ke level yang cukup rendah. Berdasarkan informasi dari Instagram @idx_channel, pada pembukaan perdagangan saham sesi I (2/3), IHSG merosot $0,7 \%$ atau 38,8 poin ke level 5.413,8.

Secara teoritis banyak faktor yang memengaruhi pergerakan harga saham, seperti Tandelilin (2010) mengemukakan harga saham sangat tergantung dari prospek keuntungan yang dimiliki perusahaan, dan keuntungan tersebut tergantung kondisi makro ekonomi seperti produk domestik bruto, tingkat pengangguran, inflasi, tingkat bunga, kurs Rupiah terhadap US dolar. Inflasi adalah suatu kejadian yang menunjukan kenaikan tingkat harga secara umum dan berlangsung secara terus menerus terus menerus (Murni, 2013 : 202). Inflasi yang meningkat mengakibatkan daya beli menurun. Artinya setiap nilai uang hanya dapat digunakan untuk membeli barang dan jasa dalam jumlah lebih sedikit. Ketika inflasi mengalami kenaikan, harga saham pendapatan biasanya akan menurun. Hal ini berarti pula bahwa memiliki saham dengan dividen akan mengalami penurunan harga saham ketika inflasi meningkat. Pada kondisi ini, investor bisa memanfaatkan situasi dengan membeli saham dengan harga murah. Faktor makro ekonomi lainnya yang memengaruhi harga saham yaitu nilai tukar mata uang atau yang sering disebut dengan kurs adalah harga satu unit mata uang asing dalam mata uang domestik atau dapat juga dikatakan harga mata uang domestik terhadap mata uang asing (Bank Indonesia, 2004:4). Harianto dan Sudomo (2001:15) menyatakan bahwa melemahnya kurs rupiah terhadap mata uang asing (depresiasi) akan meningkatkan biaya impor bahan baku untuk produksi. Hal tersebut akan berpengaruh pada menurunnya laba yang didapatkan oleh perusahaan dan mengakibatkan dividen yang dibagikan kepada pemegang saham menurun. Suku bunga dianggap mempengaruhi keputusan pribadi, bisnis, serta rumah tangga (Mishkin, 2008). Menurut Samsul (2006) naiknya suku bunga deposito akan mendorong investor untuk menjual saham dan kemudian menabung hasil penjualan itu ke dalam deposito. Penjualan saham secara besar-besaran akan menjatuhkan harga saham di pasar. Volume perdagangan saham diartikan sebagai jumlah lembar saham yang di perdagangkan pada hari tertentu ( Halim dan Hidayat, 2010). Syamsir (2006:5) mengemukakan : "asumsi dasar dalam analisis teknikal adalah bahwa harga sangat ditentukan oleh keseimbangan antara supply dan demand, jika terjadi ekses supply (kelebihan supply atas demand), maka harga akan jatuh dan demikian sebaliknya." Kelebihan penawaran saham ini mencerminkan banyaknya investor di bursa yang melepas atau menjual sahamnya.

Della Maryanne (2009), menemukan bahwa dalam kondisi-kondisi tertentu apabila tingkat inflasi kurang stabil, investor cenderung menunggu dalam hal berinvestasi pada perusahaan sektor perbankan. Marissa Gintin (2016) dalam penelitiannya menemukan bahwa naiknya tingkat inflasi akan menurunkan tingkat harga saham, hal ini dapat mempengaruhi fluktuasi harga saham pada perusahaan sektor perbankan di Indonesia. Della Maryanne (2009) dalam penelitiannya menemukan bahwa naik dan 
turunnya nilai tukar dan suku bunga dapat mempengaruhi harga saham, naiknya nilai tukar akan menurunkan tingkat harga saham. Sedangkan dalam penelitian Nurlina (2017) menemukan bahwa semakin naik suku bunga akan meningkatkan harga saham PT Bank Rakyat Indonesia, Tbk. Sunaryo (2020) menemukan bahwa faktor volume transaksi juga mempengaruhi harga saham, apabila jumlah penawaran transaksi saham semakin naik akan menurunkan tingkat harga saham pada Jakarta Islam Indeks di Bursa Efek Indonesia. Penelitian ini bertujuan untuk mengetahui pengaruh inflasi, nilai tukar, suku bunga dan volume transaksi terhadap harga saham perusahaan sektor makanan dan minuman secara parsial maupun secara simultan pada kondisi pandemi covid-19 periode maret s/d september 2020.

\section{METODE}

Metode Penelitian

Metode yang digunakan dalam penelitian ini adalah metode penelitian kuantitatif dengan analisis regresi linear berganda.

Jenis Data

Jenis data dalam penelitian ini adalah data kuantitatif dengan periode pengamatan dari bulan Maret 2020 s/d September 2020.

Sumber Data

Sumber data yang digunakan dalam penelitian ini adalah data sekunder berupa data yang mendukung variabel penelitian. Data-data tersebut yang diperoleh dari BEI www.idx.co.id , www.finance.yahoo.com, www.bi.go.id, www.sahamok.com .

Teknik Pengumpulan Data

Pengumpulan data diperoleh dari informasi dan laporan dari Bursa Efek Indonesia (ICMD), Bank Indonesia, dan website SahamOk. Laporan dari BEI dan SahamOk digunakan untuk memperoleh data sektor perusahaan makanan dan minuman yang listing di BEI dan untuk mencari data kriteria-kriteria. Bank Indonesia digunakan untuk memperoleh data tingkat suku bunga, inflasi dan nilai tukar. Akses dari www.finance.yahoo.com digunakan untuk memperoleh data harga saham bulanan dan data volume transaksi bulanan perusahaan sektor makanan dan minuman.

Teknik Analisis Data

Uji statistik deskriptif

Tujuannya untuk menguji dan menjelaskan karakteristik sampel yang diobservasi (Chandrarin, 2017).

Uji Asumsi Klasik

-Uji Normalitas

Uji normalitas bermaksud untuk menguji apakah dalam model regresi, variabel dependen dan independen saling mempunyai distribusi normal ataukah tidak. Model regresi yang baik adalah data yang berdistribusi normal atau mendekati normal (Imam Ghozhali, 2007). Dalam penelitian ini dilakukan uji normalitas data dengan menggunakan uji statistik one-sampel kolmogrov-smirnov. Berdistribusi normal dan tidaknya data penelitian dilihat dari nilai Asymp.Sig.(2-tailed) uji one-sample kolmogrov-smirnov, jika nilainya 
lebih besar dari 0,05 maka data terdistribusi normal. Sebaliknya, jika nilai Asymp.Sig.(2-tailed) lebih kecil dari 0,05 maka data tersebut tidak berdistribusi normal

-Uji Multikolinearitas

Uji multikolinearitas bertujuan untuk menguji apakah pada model regresi terdapat korelasi antara variabel bebas. Untuk mengetahui ada tidaknya multikolinearitasi ini dapat dilihat dari tolerance value atau variance inflation factor (VIF), apabila tolerance value $>0,1$ dan nilai VIF $<10$ maka tidak terjadi multikolinearitas.

-Uji Heterokedastisitas

Uji heteroskededasitas dilakukan untuk menguji apakah dalam model regresi terjadi ketidaksamaan varians residual dari pengamatan ke pengamatan lain (Ghozali, 2015). Metode yang dipakai dalam penelitian ini untuk menguji heteroskedastisitas adalah grafik Scatterplot antara nilai prediksi variabel terikat, yaitu ZPRED (sumbu X) dengan residualnya SRESID (sumbu Y). Apabila titiktitik menyebar secara acak di atas maupun di bawah angka 0 (nol) pada sumbu Y maka dikatakan tidak terjadi gejala heterokedastiditas (Imam Ghozali, 2011).

Analisis Linear Berganda

Analisis regresi linear berganda adalah hubungan secara linear antara dua atau lebih variabel independen dan variabel dependen. Dalam penelitian ini digunakan analisis data untuk menguji pengaruh variabel independen (inflasi, nilai tukar, suku bunga, volume transaksi) terhadap variabel dependen (harga saham). Model hubungan variabel akan dianalisis sesuai dengan persamaan regresi :

$\mathrm{Y}=\alpha+\beta_{1} \mathrm{Inf}+\beta_{2} \mathrm{NT}+\beta_{3} \mathrm{SuB}+\beta 4 \mathrm{Vol}+\mathrm{e}$

Dimana:

$\mathrm{Y}=$ Harga Saham

Inf $=$ Inflasi

NT = Nilai Tukar

SuB $=$ Suku Bunga

Vol $=$ Volume Transaksi

$\alpha=$ Konstanta (nilai $Y^{\prime}$ apabila Inf, Vol.....Xn = 0)

$\beta_{1}, \beta_{2}, \beta_{3}=$ Koefisien regresi (nilai peningkatan ataupun penurunan)

$\mathrm{e}=$ Error term

\section{Uji F}

Uji F dilakukan dengan tujuan untuk menguji apakah pengaruh semua variabel independen terhadap satu variabel dependen sebagaimana yang diformulasikan dalam satu model persamaan regresi linear berganda sudah tepat (fit) (Chandrarin, 2017). Jika hasil analisis menunjukkan nilai $\mathrm{p} \leq 0,05$ maka model persamaan regresinya signifikan pada alfa sebesar $5 \%$, sehingga dapat disimpulkan bahwa model 
yang diformulasikan dalam persamaan regresi linear berganda sudah tepat. Sebaliknya, jika hasil analisis menunjukkan $p>0,05$ maka model persamaan regresinnya tidak signifikan pada level alfa sebesar 5\%, sehingga dapat disimpulkan bahwa model yang diformulasikan dalam persamaan regresi linear berganda belum tepat.

\section{Uji T}

Uji t bertujuan untuk menguji signifikasi pengaruh masing-masing variabel independen terhadap variabel dependen yang diformulasikan dalam model (Chandrarin, 2017). Jika hasil analisis menunjukkan $p \leq 0,05$ maka pengaruh variabel independen terhadap satu variabel dependen adalah secara statistik segnifikan pada level alfa 5\%,sebaliknya, jika hasil analisis menunjukkan nilai $p>0,05$ maka pengaruh variabel independennya terhadap variabel dependen secara statistik tidak signifikan.

\section{Uji R ${ }^{2}$}

Koefisien determinasi atau uji uji $\mathrm{R}^{2}$ pada intinya mengukur seberapa jauh kemampuan model dalam menerangkan variasi variabel independen. Nilai koefisien determinasi adalah antara nol (0) dan satu. Nilai koefisien determinasi yang mendekati satu berarti kemampuan variabel-variabel independen memberikan hampir semua informasi yang dibutuhkan untuk memprediksi variasi dependen (Imam Ghozali, 2005).

\section{HASIL}

Analisis Deskritif

Tabel 1

Descriptive Statistics

\begin{tabular}{llllll}
\hline & $\mathrm{N}$ & Minimum & Maximum & Mean & Std. Deviation \\
\hline INFLASI(X1) & 35 & 1.32 & 2.96 & 2.0086 & .59632 \\
NILAI TUKAR(X2) & 35 & 14695.95 & 16367.43 & 15402.7100 & 492.99815 \\
SUKU BUNGA(X3) & 35 & 4.00 & 4.50 & 4.2500 & .23483 \\
VOLUME & 35 & 8500 & 243013600 & 34421325.71 & 51240309.985 \\
TRANSAKSI(X4) & 35 & & 12125 & 2677.74 & 2907.611 \\
HARGA SAHAM(Y) & 35 & 264 & & & \\
Valid N (listwise) & 35 & & & & \\
\hline
\end{tabular}

Sumber : Data Olahan SPSS

Dalam data diatas menunjukan nilai minimum pada variabel inflasi sebesar 1,32\%, nilai maksimum sebesar $2,96 \%$ dan nilai rata-rata sebesar $02,0086 \%$. Nilai minimum variabel nilai tukar dalam data diatas sebesar Rp. 14695,95, nilai maksimum sebesar Rp. 16367,43 dan nilai rata-rata sebesar Rp. 15402,7100. Nilai minimum variabel suku bunga berdasarkan data diatas sebesar $4,00 \%$, nilai maksimum sebesar $4,50 \%$ dan nilai rata-rata sebesar $4,2500 \%$. Nilai minimum variabel volume transaksi berdasarkan data diatas sebesar Rp. 8.500, nilai maksimum sebesar Rp. 243.013.600 dan nilai rata-rata sebesar Rp. 34.421.325,71. Nilai minimum variabel harga saham berdasarkan data diatas sebesar Rp. 264, nilai maksimum sebesar Rp. 12.125 dan nilai rata-rata sebesar Rp. 2.677,74. 
Uji Normalitas

Hasil pengujian One-sample kolmogrov-smirnov test adalah sebagai barikut:

Tabel 2

One-Sample Kolmogorov-Smirnov Test

\begin{tabular}{lll}
\hline & & $\begin{array}{l}\text { Unstandardize } \\
\text { d Residual }\end{array}$ \\
\hline $\mathrm{N}$ & Mean & 35 \\
Normal Parameters & \\
& Std. Deviation & .0000000 \\
Most Extreme Differences & Absolute & $7.39048040 \mathrm{E} 3$ \\
& Positive & .120 \\
& Negative & .120 \\
Kolmogorov-Smirnov Z & & -.078 \\
Asymp. Sig. (2-tailed) & & .713 \\
\hline
\end{tabular}

a. Test distribution is Normal.

Sumber : Data Olahan SPSS

Berdasarkan ouput diatas, diketahui bahwa nilai signifikan sebesar 0,868 lebih besar dari a 0,05 sehingga dapat disimpulkan bahwa data yang diuji berdistribusi normal.

Uji Multikolinearitas

Hasil uji multikolinearitas adalah sebagai berikut:

Tabel 3

Coefficients $^{\mathrm{a}}$

\begin{tabular}{llll}
\hline \multicolumn{2}{l}{ Model } & & \multicolumn{2}{l}{ Collinearity Statistics } \\
\hline 1 & & Tolerance & VIF \\
\hline & NTf & .142 & 7.050 \\
& SuB & .516 & 1.937 \\
& Vol & .984 & 7.984 \\
\multicolumn{2}{l}{ a. Dependent Variable: Harga Saham }
\end{tabular}

Sumber : Data Olahan SPSS

Nilai Tolerance variabel inflasi sebesar 0,142, nilai tukar sebesar 0,516, suku bunga sebesar 0,125, dan volume transaksi sebesar 0,984 lebih besar dari 0,10. Sedangkan nilai VIF lebih kecil dari 10,00 yaitu inflasi sebesar 7,050, nilai tukar sebesar 1,937, suku bunga sbesar 7,984, dan volume transaksi sebesar 1,016. Sehingga disimpulkan tidak terjadi multikolinearitas. 
Uji Heterokedastisitas

Uji ini menggunakan metode grafik scatter plots sebagai berikut :

\section{Scatterplot}

Dependent Variable: Harga Saham

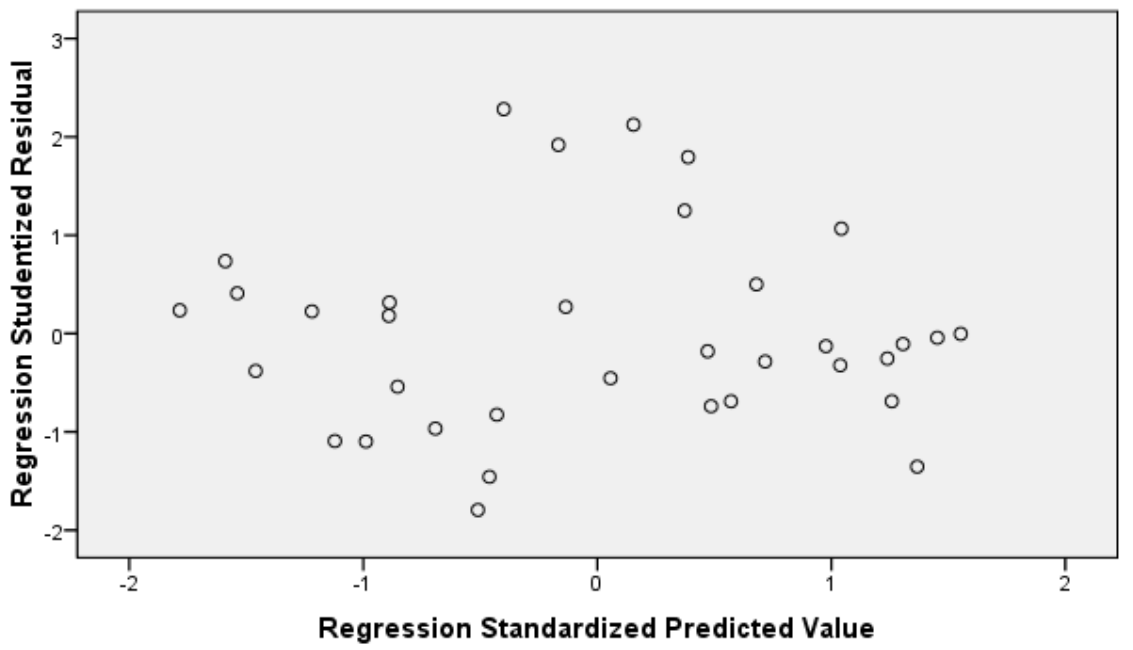

Gambar 1

Sumber : Data Olahan SPSS

Berdasarkan output diatas, terlihat bahwa titik-titik menyebar dan tidak membentuk pola tertentu. Sehingga dapat disimpulkan bahwa tidak terjadi masalah heterokedastisitas.

Analisis Linear Berganda

Hubungan antara inflasi, nilai tukar, suku bunga dan volume transaksi terhadap harga saham perusahaan menghasilkan suatu persamaan sebagai berikut :

$\mathrm{Y}=\alpha+\beta_{1} \mathrm{Inf}+\beta_{2} \mathrm{NT}+\beta_{3} \mathrm{SuB}+\beta 4 \mathrm{Vol}+\mathrm{e}$

$\mathrm{Y}=4898,583-0,227 \mathrm{Inf}+0,017 \mathrm{NT}+0,241 \mathrm{SuB}+0,697 \mathrm{Vol}+\mathrm{e}$

Berdasarkan persamaan diatas dioperoleh konstanta sebesar 4898,583 bernilai positif. Hal ini berarti bahwa jika inflasi, nilai tukar, suku bunga dan volume transaksi bernilai konstan atau nol (0) maka akan meningkatkan nilai harga saham sebesar 4898,583 atau 48,98\%.

Nilai koefisien inflasi sebesar -0,227, yang menunjukan jika variabel inflasi (Inf) berpengaruh negarif artinya apabila inflasi meningkat satu point maka harga saham $(\mathrm{Y})$ akan turun sebesar -0,227 atau $-22,7 \%$ dengan asumsi variabel lain dianggap konstan. 
Nilai koefisien nilai tukar sebesar 0,017, yang menunjukan jika variabel nilai tukar (NT) berpengaruh positif artinya apabila nilai tukar meningkat satu point maka harga saham (Y) akan naik sebesar 0,017 atau sebesar 1,7\% dengan asumsi variabel lain dianggap konstan.

Nilai koefisien suku bunga sebesar 0,241, yang menunjukan jika variabel suku bunga (SuB) berpengaruh positif artinya apabila suku bunga meningkat satu point maka harga saham (Y) akan naik sebesar 0,241 atau sebesar 24,1\% dengan asumsi variabel lain dianggap konstan.

Nilai koefisien volume transaksi sebesar 0,697, yang menunjukan jika variabel volume transaksi (Vol) berpengaruh positif artinya apabila volume transaksi meningkat satu point maka harga saham (Y) akan naik sebesar 0,697 atau sebesar 69,7\% dengan asumsi variabel lain dianggap konstan.

Uji F

Hipotesis pertama dalam penelitian ini ditunjukkan pada tabel berikut :

Tabel 4

\begin{tabular}{lllllll}
\multicolumn{7}{c}{ ANOVA $^{\mathrm{b}}$} \\
\hline Model & & Sum of Squares df & Mean Square & $\mathrm{F}$ & Sig. \\
\hline 1 & Regression & $1.712 \mathrm{E} 9$ & 4 & $4.281 \mathrm{E} 8$ & 6.916 & $.000^{\mathrm{a}}$ \\
& Residual & $1.857 \mathrm{E} 9$ & 30 & $6.190 \mathrm{E} 7$ & & \\
& Total & $3.569 \mathrm{E} 9$ & 34 & & & \\
\hline
\end{tabular}

a. Predictors: (Constant), Vol, Inf, NT, SuB

b. Dependent Variable: Harga Saham

Sumber : Data Olahan SPSS

Berdasarkan tabel gambar diatas, diperoleh nilai $\mathrm{F}$ sebesar 6,916 dengan nilai signifikan sebesar 0,000 < 0,05, maka dapat disimpulkan bahwa inflasi, nilai tukar, suku bunga, dan volume transaksi berpengaruh secara simultan terhadap harga saham.

Uji T

Hipotesis kedua dalam penelitian ini menggunakan uji t. hasil penelitian ditunjukkan dalam tabel berikut : 
Tabel 5

\begin{tabular}{lllllll}
\multicolumn{7}{c}{ Coefficients $^{\mathrm{a}}$} \\
\hline \multicolumn{7}{c}{ Unstandardized Coefficients Coefficients } \\
\multicolumn{1}{c}{} & & \multicolumn{7}{c}{ Standardized } \\
\hline 1 & & B & Std. Error & Beta & $\mathrm{t}$ & Sig. \\
\hline & (Constant) & 4898.583 & 4007.825 & & 1.222 & .231 \\
& Inf & -.227 & .353 & -.225 & -.642 & .526 \\
& NT & .017 & .185 & .017 & .094 & .925 \\
& SuB & .241 & .406 & .221 & .593 & .558 \\
& Vol & .697 & .133 & .697 & 5.248 & .000 \\
\hline
\end{tabular}

a. Dependent Variable: Harga Saham

Sumber : Data Olahan SPSS

Hasil pengujian hipotesis masing-masing variabel independen secara parsial terhadap variabel dependen dapat dianalisis sebagai berikut:

Pengaruh Inflasi Terhadap Harga Saham

Berdasarkan uji statistik secara parsial menunjukan nilai signifikan inflasi sebesar 0,526 > 0,05, yang berarti inflasi tidak berpengaruh signifikan terhadap harga saham. Koefisien variabel tingkat inflasi sebesar -0,227 menunjukan angka negatif, yang artinya tingkat inflasi berhubungan negatif terhadap harga saham.

Pengaruh Nilai Tukar terhadap Harga Saham

Berdasarkan uji statistik secara parsial diatas, menunjukan nilai signifikan nilai tukar sebesar 0,925 > 0,05, yang berarti nilai tukar tidak berpengaruh signifikan terhadap harga saham. Koefisien variabel nilai tukar sebesar 0,017 menunjukan angka positif, yang artinya nilai tukar berhubungan positif terhadap harga saham.

Pengaruh Suku Bunga terhadap Harga saham

Berdasarkan uji statistic secara parsial diatas, menunjukan nilai signifikan suku bunga sebesar 0,558 > 0,05, yang berarti nilai tukar tidak berpengaruh signifikan terhadap harga saham. Koefisien variabel suku bunga sebesar 0,241 menunjukan angka positif, yang artinya suku bunga berhubungan positif terhadap harga saham.

Pengaruh Volume Transaksi terhadap Harga Saham

Berdasarkan uji statistik secara parsial diatas, menunjukan nilai signifikan volume transaksi sebesar $0,000<0,05$, yang berarti volume transaksi berpengaruh signifikan terhadap harga saham. Koefisien variabel volume transaksi sebesar 0,697 menunjukan angka positif, yang artinya volume transaksi berhubungan positif terhadap harga saham.

Uji $R^{2}$

Analisis Koefisien Determinasi 
Analisis koefisien determinasi dalam penelitian ini menggunakan dasar adjusted $R^{2}$. Hasil penelitian ditunjukkan pada tabel berikut :

Tabel 6

$$
\text { Model Summary }
$$

\begin{tabular}{lllll}
\hline Model & $\mathrm{R}$ & R Square & $\begin{array}{l}\text { Adjusted R } \\
\text { Square }\end{array}$ & $\begin{array}{l}\text { Std. Error of } \\
\text { the Estimate }\end{array}$ \\
\hline 1 & $.693^{\mathrm{a}}$ & .480 & .410 & 7867.767 \\
\hline
\end{tabular}

a. Predictors: (Constant), Vol, Inf, NT, SuB

b. Dependent Variable: Harga Saham

Sumber : Data Olahan SPSS

Hasil pengolahan data diatas menunjukkan bahwa nilai $\mathrm{R}$ Square sebesar 0,480 atau $48 \%$. Hal ini dapat diartikan bahwa besarnya pengaruh inflasi, nilai tukar, suku bunga dan volume transaksi terhadap harga saham perusahaan dalam penelitian ini sebesar $48 \%$. Sedangkan sisanya $52 \%$ dipengaruhi oleh variabel lain.

\section{PEMBAHASAN}

Penelitian ini dilakukan untuk menjelaskan pengaruh inflasi, nilai tukar, suku bunga, dan volume transaksi terhadap harga saham pada perusahaan pada kondisi pandemi Covid-19 (studi empiris pada perusahaan sektor makanan dan minuman yang terdaftar di BEI periode maret s/d september 2020). Berikut ini adalah pembahasan dari masing-masing variabel yang terkait dalam penelitian ini.

Pengaruh Inflasi Terhadap Harga Saham

Hasil penelitian ini menunjukan bahwa variabel bebas tingkat inflasi memiliki pengaruh negatif dan tidak signifikan terhadap harga saham ditujukan dari nilai signifikan sebesar 0,526 > 0,05. Berarti inflasi tidak berpengaruh signifikan terhadap harga saham.

Arah hubungan yang ditunjukan dalam hasil penelitian ini adalah negatif. Hasil pengujian ini menunjukan bahwa semakin besar inflasi pada kondisi pandemi maka harga saham perusahaan sektor makanan dan minuman akan semakin menurun. Hasil penelitian ini sejalan dengan penelitian terdahulu oleh Maria Ratna Marisa Ginting (2016), yang menyatakan bahwa inflasi berpengaruh negatif terhadap harga saham. Pengaruh kenaikan inflasi saat pandemi tidak secara signifikan menurunkan harga saham namun tetap berpengaruh dan dikarenakan kenaikan inflasi yang masih dalam kategori rendah yaitu tingkat inflasi dibawah $10 \%$.

Pengaruh Nilai Tukar Terhadap Harga Saham

Hasil penelitian ini menunjukan bahwa variabel bebas nilai tukar memiliki pengaruh positif dan tidak signifikan terhadap harga saham yang ditunjukan dari signifikan sebesar 0,925 > 0,05. Berarti nilai tukar tidak berpengaruh signifikan terhadap harga saham. 
Hal ini mengindikasikan bahwa setiap adanya kenaikan nilai tukar pada saat pandemi akan meningkatkan harga saham perusahaan sektor makanan dan minuman walaupun tidak secara signifikan. Hasil penelitian ini tidak sejalan dengan penelitian terdahulu oleh Donna Menina Della Maryanne (2009) yang menyatakan bahwa nilai tukar berpengaruh negative terhadap harga saham. Diindikasikannya nilai tukar dapat meningkatkan harga saham dikarenakan permintaan luar negri akan kebutuhan makanan dan minuman yang cukup besar sehingga dapat meningkatkan harga saham perusahaan.

Pengaruh Suku Bunga Terhadap Harga Saham

Hasil penelitian ini menunjukan bahwa variabel bebas suku bunga memiliki pengaruh positif dan tidak signifikan terhadap harga saham yang ditunjukan dari nilai signifikan sebesar $0,558>0,05$. Berarti suku bunga tidak berpengaruh signifikan terhadap harga saham.

Hal ini mengindikasikan bahwa semakin besar tingkat suku bunga pada masa pandemi akan meningkatkan harga saham perusahaan sektor makanan dan minuman meskipun meningkatnya harga saham tidak secara signifikan. Hasil penelitian ini sejalan dengan penelitian terdahulu oleh Nurliana (2017) yang menyatakan bahwa suku bunga berpengaruh positif terhadap harga saham. Peningkatan suku bunga pada masa pandemi yang tidak terlalu tinggi membuat investor tetap mempertahankan investasi dalam saham dan tidak berpindah pada kegiatan menabung dibank, hal ini juga mengindikasikan bahwa tingkat kepercayaan dalam berinvestasi di perusahaan sektor makanan dan minuman meningkat.

Pengaruh Volume Transaksi Terhadap Harga Saham

Hasil penelitian ini menunjukan bahwa variabel bebas volume transaksi memiliki pengaruh positif dan signifikan terhadap harga saham yang ditunjukan dari nilai signifikan sebesar 0,000 < 0,05 dan H4 ditolak. Berarti volume transaksi berpengaruh signifikan terhadap harga saham.

Hal ini mengindikasikan bahwa semakin besar tingkat volume transaksi pada saat pandemi akan meningkatkan harga saham perusahaan sektor makanan dan minuman. Penelitian ini tidak sejalan dengan penelitian terdahulu oleh Sunaryo (2020) yang menyatakan bahwa volume transaksi berpengaruh negatif terhadap harga saham. Meningkatnya volume transaksi yang menyebabkan naiknya harga saham ini mencerminkan banyaknya permintaan akan saham dari investor di masa pandemi Covid-19. Dari hasil ini dapat disimpulkan bahwa pada masa pandemi Covid-19 banyak investor-investor baru yang bermunculan akibat dari peraturan pemerintah yaitu bekerja dari rumah sehingga banyak orang yang mengambil keputusan untuk berinvestasi.

Pengaruh Inflasi, Nilai Tukar, Suku Bunga Dan Volume Transaksi Terhadap Harga Saham

Hasil penelitian ini menunjukan bahwa variabel bebas inflasi, nilai tukar, suku bunga dan volume transaksi berpengaruh signifikan secara simultan terhadap harga saham, ditunjukan dari nilai signifikan $0,000<0,05$, sehingga dapat disimpulkan bahwa inflasi, nilai tukar, suku bunga dan volume transaksi berpengaruh signifikan secara simultan terhadap harga saham.

\section{SIMPULAN DAN SARAN}

Penelitian ini meneliti bagaimana pengaruh inflasi, nilai tukar, suku bunga, dan volume transaksi terhadap harga saham perusahaan pada kondisi pandemi Covid-19 (studi empiris pada perusahaan sektor 
makanan dan minuman yang terdaftar di BEI periode maret s/d september 2020). Sesuai dengan hasil pengujian yang dilakukan, maka dapat disimpulkan sebagai berikut:

Hasil pengujian pertama diperoleh bahwa tidak ada pengaruh yang signifikan antara inflasi terhadap harga saham secara parsial. Hasil ini menunjukan bahwa kondisi inflasi pada masa pandemi menyebabkan investor cenderung untuk melakukan penawaran saham karena semakin tinggi inflasi pada periode penelitian ini akan menurunkan harga saham.

Hasil pengujian kedua diperoleh bahwa tidak ada pengaruh yang signifikan antara nilai tukar terhadap harga saham secara parsial. Tidak adanya pengaruh yang signifikan disebabkan karena transaksi yang terjadi pada perusahaan lebih banyak manggunakan mata uang rupiah daripada mata uang asing dan perusahaan yang digunakan merupakan perusahaan sektor makanan dan minuman bukan sektor ekspor maupun impor sehingga tidak berpengaruh secara signifikan terhadap harga saham perusahaan.

Hasil pengujian ketiga diperoleh bahwa tidak ada pengaruh yang signifikan antara suku bunga terhadap harga saham secara parsial. Dari hasil penelitian ini menyatakan bahwa semakin tinggi suku bunga pada masa pandemi maka harga saham akan meningkat sehingga dapat disimpulkan bahwa tingkat kepercayaan investor meningkat dalam menanamkan sahamnya di perusahaan sektor makanan dan minuman.

Hasil pengujian keempat diperoleh bahwa ada pengaruh signifikan dan positif antara volume transaksi terhadap harga saham secara parsial. Hal ini menunjukan bahwa volume transaksi yang tinggi pada masa pandemi mengindikasikan banyaknya investasi yang masuk ke perusahaan sektor makanan dan minuman, sehingga menyebabkan harga saham perusahaan menjadi meningkat.

Hasil pengujian secara simultan diperoleh bahwa pengaruh variabel inflasi, nilai tukar, suku bunga, dan volume transaksi berpengaruh signifikan terhadap harga saham perusahaan di masa pandemi. Yang berarti secara bersama-sama variabel independen berpengaruh signifikan terhadap variabel dependen.

\section{Saran-Saran}

Bagi investor dapat menjadikan volume transaksi sebagai informasi dalam penanaman investasinya di masa pandemi karena terbukti bahwa volume transaksi berpengaruh terhadap peningkatan harga saham. Dan faktor yang harus diperhatikan lebih teliti adalah faktor inflasi karena sudah terbukti berdampak pada menurunnya harga saham perusahaan.

Bagi peneliti selanjutnya, diharapkan jika ingin mengambil penelitian sejenis alangkah baiknya menggunakan variabel lain yang berpengaruh signifikan terhadap harga saham. Selain itu, dapat juga menggunakan sampel penelitian yang lain dan sektor perusahaan yang lain dengan periode yang berbeda.

\section{DAFTAR PUSTAKA}

Ariyani Indriastuti dan Zumrotun Nafiah. (2017). Pengaruh Volume perdagangan, Kurs dan Risiko Pasar terhadap Return Saham. 2017. Jurnal STIE SEMARANG ,VOL 9 No. 1 Edisi Februari 2017

Camelia (2020, April 9). Tangis Pilu Puluhan Karyawan Ramayana Depok Terkena PHK Akibat Corona. Dibaca April, 18, 2020, dari https://www.liputan6.com/citizen6/read/4222812/tangis-pilupuluhan-karyawanramayana-depok-terkena-phk-akibat-corona. 
Efni Yulia. Pengaruh Suku Bunga Deposito, SBI, Kurs dan Inflasi terhadap Harga Saham Perusahaan Real Estate dan Property di BEI. Skripsi.

Ginting, Maria R. M. (2016). Pengaruh Tingkat Suku Bunga, Nilai Tukar dan Inflasi terhadap Harga Saham (Studi Pada Sub-Sektor Perbankan Di Bursa Efek Indonesia Periode 2011-2015). 2016. Jurnal Administrasi Bisnis. Vol. 35. No. 2 Juni 2016.

Maryanne, Donna M.D.(2009). Pengaruh Nilai Tukar Rupiah, Suku bunga SBI, Volume Perdagangan Saham, Inflasi dan Beta Saham Terhadap Harga Saham (Studi Empiris pada Perusahaan Sektor Perbankan Di Bursa Efek Indonesia Periode 2004-2007). 2009. Tesis. 27 Mei 2009.

Nurlina. (2017). Pengaruh Nilai Tukar dan Suku Bunga Terhadap Harga Saham PT. Bank Rakyat Indonesia Tbk. 2017. Jurnal Samudra Ekonomika. VOL.1, NO. 1 April 2017

Nurmasari Ifa. (2020). Dampak Covid-19 Terhadap Perubahan Harga Saham dan Volume Transaksi (Studi Kasus Pada PT. Ramayana Lestari Sentosa, Tbk.).2020. Jurnal Sekuritas (Saham, Ekonomi, Keuangan dan Investasi ). Vol.3, No. 3, Mei 2020

Putri. Hana Tamara. (2020). Covid 19 dan Harga Saham Perbankan di Indonesia.2020. Jurnal Ilmiah Ekonomi dan Bisnis, 11(1), Mei 2020, 6-9

Rifa'i. M. Hasan dan Junaidi dan Arista Fauzi Kartika Sari. (2020). Pengaruh Peristiwa Pandemi Covid-19 Terhadap Indeks Harga Saham Gabungan.2020. E-JRA Vol. 09 No. 06 Agustus 2020

Siswantoro. (2020). Efek diumumkannya kasus pertama Covid-19 terhadap harga saham dan total saham yang diperdagangkan (The effect of the first Covid-19 case announcement on stock prices and stock trading totals).2020. Jurnal Akuntansi, Keuangan, dan Manajemen (Jakman). Vol 1, No 3, 2020, 227 238.

Shiyammurti.Nastiti Rizky. (2020). Dampak Pandemi Covid-19 Di PT. Bursa Efek Indonesia ( BEI ).2020. Journal of Accounting Taxing and Auditing (JATA) ISSN: - Vol. 1, No. 1, Februari 2020

Sunaryo. (2020). Pengaruh Volume Offer Saham Terhadap Harga Saham (Studi Empiris Pada SahamSaham Jakarta Islamic Index DI Bursa Efek Indonesia Periode Januari - April 2020) Kajian Penelitian Pada Kondisi Pandemi Virus Covid-19.2020. Jurnal Ekonomi dan Bisnis Vol. 2 No. 2 Juni 2020

Sholihah Mar'atus. (2014). Analisis Pengaruh Suku Bunga, inflasi, dan Nilai Tukar Terhadap Harga Saham Perusahaan Jasa Perhotelan dan Pariwisata yang terdaftar di Bursa Efek Indonesia. 2014. Karya Ilmiah. 21 Februari 2014

Savira, Rahmadya dan Dheo Rimbano. (2016). Pengaruh Suku Bunga dan Kurs terhadap Harga Saham Perusahaan Real Estate dan Property (Kajian Empiris Pada Bursa Efek Indonesia) Periode Bulanan 2013-2014. 2016. Artikel. 15 Oktober 2016

Shiyammurti, Nastiti Rizky. Dwi Aggraeni Saputri dan Euis Syafira. (2020). Dampak Pandemi Covid-19 di PT Bursa Efek Indonesia (BEI). 2020. Jurnal of Accounting Taxing and Auditing (JATA). Vol. 1. No. 1. Februari 2020.

Tambunan.Diana. (2020). Investasi Saham di Masa Pandemi Covid-19.2020. Jurnal Sekretari dan Manajemen. Volume 4 No. 2 September 2020 
Data Suku Bunga Bulanan. Dibaca 02 Oktober 2020. Dari https://www.bi.go.id/id/moneter/bi-7dayRR/data/Contents/Default.aspx

Data Daftar Harga Saham dan Volume Transaksi Perusahaan Yang Terdaftar Di BEI. Dibaca 30 September 2020. Dari https:// finance.yahoo.com/

Dibaca 30 September 2020. Dari https://www.bi.go.id/id/statistik/indikator/data-inflasi.aspx

Data Tingkat Nilai Tukar atau Kurs Bulanan. Dibaca 12 Desember 2020. Dari https://www.bi.go.id/id/statistik/informasi-kurs/jisdor/Default.aspx

Data Perusahaan-Perusahaan Yang Terdaftar di BEI. Dibaca 25 September 2020. Dari https://www.idx.co.id/perusahaan-tercatat/profil-perusahaan-tercatat/

Data Perusahaan-Perusahaan Bersaham Syariah di BEI. Dibaca 25 September 2020. Dari https:// www.sahamok.net/emiten/sektor-industri-barang-konsumsi/sub-sektor-makananminuman/ 